\title{
Appellate Body Report on EU-Biodiesel: The Future of China's State Capitalism under the WTO Anti-Dumping Agreement
}

\author{
WEIHUAN ZHOU * \\ Faculty of Law, UNSW Sydney, Australia
}

\begin{abstract}
China's unique economic system poses increasing challenges to the world trading system and attracts growing academic and policy debate. WTO members have frequently resorted to antidumping measures in dealing with price distortions caused by the Chinese government's influence on the economy. The Appellate Body's decision in the recent EU-Biodiesel dispute starts to remove the flexibility of condemning state intervention and price distortions under the WTO Anti-Dumping Agreement through antidumping measures. This decision, read with the relevant WTO jurisprudence on the 'ordinary course of trade' test and subsidies, suggests that price distortions resulting from state intervention should be addressed under other WTO rules. Therefore, it is necessary for WTO members to shift their focus to, and explore the capacity of, the other rules to overcome the challenges arising from China's state capitalism.
\end{abstract}

\section{Introduction}

The term 'state capitalism' is used to describe the situation in an economy where government influence or state intervention is widespread. ${ }^{1}$ While state capitalism exists in both developing and developed economies, ${ }^{2}$ China has been at the centre of academic and policy discussions for well-known reasons, such as China's growing influence on global economic activities, the dominant role of state-owned enterprises ('SOEs') in the Chinese economy, ${ }^{3}$ the complex web of

\footnotetext{
*Email: weihuan.zhou@unsw.edu.au.

The author thanks Mr Jan Bohanes, Professor Alan Winters, and two anonymous reviewers for insightful comments. All errors or oversights are my own. All websites cited are current as of 1 October 2017.

1 See, e.g., Aldo Musacchio and Sergio G. Lazzarini, 'Leviathan in Business: Varieties of State Capitalism and their Implications for Economic Performance', Harvard Business School Working Paper 12-108, 4 June 2012, 1-63 at 3-4.

2 Ibid. Also see The Organisation for Economic Co-operation and Development (OECD), 'The Size and Sectoral Distribution of SOEs in OECD and Partner Countries', 8 September 2014, www.oecd.org/daf/ca/ size-sectoral-distribution-soes-oecd-partner-countries.htm; OECD, State-Owned Enterprises in the Development Process (Paris: OECD Publishing, 2015), www.oecd.org/corporate/state-owned-enter prises-in-the-development-process-9789264229617-en.htm.

3 See Ming Du, 'China's State Capitalism and World Trade Law' (2014) 63 International and Comparative Law Quarterly 409-448 at 411.
} 
networks and state-business relationships embedded in China's unique economic structure, ${ }^{4}$ and China's continuous SOE reforms and transformation to a market economy. ${ }^{5}$ Thus, while state capitalism is a global issue and poses increasing challenges to the international economic law order, ${ }^{6}$ considerable attention has been paid to China, particularly how the multilateral trade rules, established under the auspices of World Trade Organization ('WTO') (and its predecessor the General Agreement on Tariffs and Trade ('GATT') ${ }^{7}$ ), cope with China's state capitalism. $^{8}$

The GATT was negotiated among a group of market economy countries; state trading, however, was included in the negotiations and was considered to be distortive and a potential barrier to trade. ${ }^{9}$ This is because state trading, as one form of state intervention in an economy, may constitute an evasion of the general rules (e. g. non-discrimination) and specific commitments (e.g. tariff concessions) concluded under the GATT and now the WTO. ${ }^{10}$ Therefore, under the GATT, there were rules to tackle 'state capitalism', in anticipation of the admission of non-marketeconomies ('NMEs') into the multilateral trading system. ${ }^{11}$ The main ones include GATT Article XVII ‘State Trading Enterprises’ ('STEs’) which imposes a

4 See generally Mark Wu, 'The “China, Inc.” Challenge to Global Trade Governance' (2016) 57(2) Harvard International Law Journal 261-324; Yuhua Wang, 'Beyond Local Protectionism: China's State - Business Relations in the Last Two Decades' (2016) 226 The China Quarterly 319-341; Li-Wen Lin, 'A Network Anatomy of Chinese State-Owned Enterprises' (2016) 16(4) World Trade Review 583-600.

5 See generally Andrew Szamosszegi and Cole Kyle, 'An Analysis of State-Owned Enterprises and State Capitalism in China', US-China Economic and Security Review Commission, 26 October 2011, www.uscc.gov/sites/default/files/Research/10_26_11_CapitalTradeSOEStudy.pdf; Luyao Che, 'Legal Implications of the Deepened Reform of Chinese State-Owned Enterprises: What Can be Expected from Recent Reforms?’ (2016) 8 Tsinghua China Law Review 171-190.

6 See generally Ines Willemyns, 'Disciplines on State-Owned Enterprises in International Economic Law: Are We Moving in the Right Direction?' (2016) 19(3) Journal of International Economic Law 657-680.

7 General Agreement on Tariffs and Trade, opened for signature 30 October 1947, 61 Stat. A-11, T.I.A.S. 1700,55 U.N.T.S. 194.

8 The European University Institute has recently produced a series of working papers on this issue, which are included in the October 2017 issue of the World Trade Review. See, e.g., Petros Mavroidis and Merit Janow, 'Free Markets, State Involvement, and the WTO: Chinese State-Owned Enterprises in the Ring' (2017) 16(4) World Trade Review 571-581; Robert Wolfe, 'Sunshine over Shanghai: Can the WTO Illuminate the Murkey World of Chinese SOEs?' (2017) 16(4) World Trade Review 713-732. State trading and the capacity of the world trade law to deal with state trading was one of the first topics of the World Trade Forum established in 1997, see Thomas Cottier and Petros Mavroidis (eds.), State Trading in the Twenty-First Century (The University of Michigan Press, 1998).

9 Andrea Mastromatteo, 'WTO and SOEs: Article XVII and Related Provisions of the GATT 1994' (2017) 16(4) World Trade Review 601-618 at 601-604.

10 See generally William Davey, 'Article XVII GATT: An Overview' in Thomas Cottier and Petros Mavroidis (eds.), State Trading in the Twenty-First Century (The University of Michigan Press, 1998) $17-36$.

11 See above note 8, Mavroidis and Janow, 'Chinese State Owned Enterprises in the Ring', at 571. 
general obligation of non-discrimination on STEs, ${ }^{12}$ and the second interpretative note to GATT Article VI: 1 which permits deviation from the standard methodology to calculate normal value in antidumping investigations when dealing with NMEs. ${ }^{13}$ These rules are limited: while the former leaves many other ways of state intervention other than discrimination unregulated, ${ }^{14}$ the latter was intended to deal with the extreme market conditions in some countries (such as Poland, Romania, and Hungary) where markets were dominated by state monopolies. ${ }^{15}$ While the other GATT/WTO rules, including the WTO Agreement on Subsidies and Countervailing Measures ('SCM Agreement'), ${ }^{16}$ may also apply to state intervention, the standard practice has been to deal with issues specific to NMEs via negotiations of their individual accession to the WTO. ${ }^{17}$ As widely noted, China's Protocol of Accession to the WTO ('Accession Protocol') contains the most comprehensive WTO-plus obligations on NME matters. ${ }^{18}$

Among China's WTO-plus obligations, the most frequently invoked has been Article 15 of the Accession Protocol, which essentially allows WTO members to treat China as an NME in antidumping investigations and consequently to replace Chinese domestic prices or costs with those of a market economy third country in determining normal value (known as the 'NME Methodology'). This

12 Article XVII:1(a) states: 'Each contracting party undertakes that if it establishes or maintains a State enterprise, wherever located, or grants to any enterprise, formally or in effect, exclusive or special privileges, such enterprise shall, in its purchases or sales involving either imports or exports, act in a manner consistent with the general principles of non-discriminatory treatment prescribed in this Agreement for governmental measures affecting imports or exports by private traders.'

13 The second Supplementary Provision to GATT Article VI:1 reads: 'It is recognized that, in the case of imports from a country which has a complete or substantially complete monopoly of its trade and where all domestic prices are fixed by the State, special difficulties may exist in determining price comparability for the purposes of paragraph 1 , and in such cases importing contracting parties may find it necessary to take into account the possibility that a strict comparison with domestic prices in such a country may not always be appropriate.'

14 For a review of the relevant case law, see above note 9, Mastromatteo, 'WTO and SOEs: Article XVII and Related Provisions of the GATT 1994'.

15 GATT Analytical Index, Article VI Anti-Dumping and Countervailing Duties, at 228, www.wto. org/english/res_e/booksp_e/gatt_ai_e/art6_e.pdf. Also see David Palmeter, 'The WTO Antidumping Agreement and the Economies in Transition' in Thomas Cottier and Petros Mavroidis (eds.), State Trading in the Twenty-First Century (The University of Michigan Press, 1998) 115-119 at 117.

16 Agreement on Subsidies and Countervailing Measures, 15 April 1994, Marrakesh Agreement Establishing the World Trade Organization, Annex 1A, 1869 U.N.T.S. 14. For a discussion of how state trading is dealt with under the SCM Agreement, see generally Gary Horlick and Kristin Heim Mowry, 'The Treatment of Activities of State Trading Enterprises under the WTO Subsidies Rules' in Thomas Cottier and Petros Mavroidis (eds.), State Trading in the Twenty-First Century (The University of Michigan Press, 1998) 97-113.

17 Two other major transitional economies which made WTO-plus commitments on NME matters are Vietnam and Russia. See Report of the Working Party on the Accession of Viet Nam, WT/ACC/VNM/48 (27 October 2006). Report of the Working Party on the Accession of the Russian Federation to the World Trade Organization, WT/ACC/RUS/70, WT/MIN(11)/2 (17 November 2011).

18 See Protocol on the Accession of the People's Republic of China, WT/L/432 (23 November 2001); above note 8, Mavroidis and Janow, 'Chinese State Owned Enterprises in the Ring', at 575. 
provision is preferred by WTO members as the WTO Anti-Dumping Agreement ('AD Agreement') ${ }^{19}$ provides very few options to deal with NMEs, ${ }^{20}$ as will be shown later in this article. However, Article 15 envisaged an expiration date for the use of the NME Methodology, that is, 15 years after the date of China's WTO accession or 11 December 2016. Since 2016, Article 15 has come to the fore in the international trade law circles as trade scholars, practitioners, and policymakers debate over whether WTO members may continue to apply the NME Methodology after its expiration date ${ }^{21}$ and whether a similar approach can be undertaken under the AD Agreement. ${ }^{22}$ In practice, major users of antidumping have employed either Article 15 of China's Accession Protocol or the AD Agreement. For example, while the US and the EU have predominantly relied on Article 15, Australia has consistently treated China as having a 'Particular Market Situation' ('PMS') in antidumping investigations and relied on Article 2.2 of the AD Agreement. ${ }^{23}$ The common effect of these approaches has been to inflate normal value through the use of surrogate prices or costs for the calculation of normal value, thereby inflating dumping margins and antidumping duties. These antidumping users believe that their approaches are justified as the prices or costs in the Chinese market are distorted or artificially lowered as a result of Chinese government intervention.

It is against this backdrop that the EU-Biodiesel dispute was adjudicated at the WTO. This dispute went through the WTO panel and Appellate Body stages with the tribunal reports adopted by the WTO Dispute Settlement Body on 26 October 2016. ${ }^{24}$ While the tribunals' rulings do not respond to the ongoing debate over

19 Agreement on the Implementation of Article VI of GATT 1994, 15 April 1994, Marrakesh Agreement Establishing the World Trade Organization, Annex 1A, 1868 U.N.T.S. 201.

20 See above note 15, Palmeter, 'The WTO Antidumping Agreement and the Economies in Transition', at 115 .

21 See, e.g., Edwin Vermulst, Juhi Dion Sud, and Simon Evenett, 'Normal Value in Anti-Dumping Proceedings against China Post-2016: Are Some Animals Less Equal Than Others?' (2016) 11(5) Global Trade and Customs Journal 212-228; J. Miranda, 'Interpreting Paragraph 15 of China's Protocol of Accession' (2014) 9(3) Global Trade and Customs Journal 94-103; T.P. Stewart, W.A. Fennell, S.M. Bell, and N.J. Birch, 'The Special Case of China: Why the Use of a Special Methodology Remains Applicable to China after 2016' (2016) 9(6) Global Trade and Customs Journal 272-279; David Kleimann, 'The Vulnerability of EU Anti-Dumping Measures against China after December 11, 2016', EUI Working Papers RSCAS 2016/37, July 2016, 1-10.

22 See, e.g., Jochem de Kok, 'The Future of EU Trade Defence Investigations against Imports from China' (2016) 19(2) Journal of International Economic Law 515-547; Weihuan Zhou and Andrew Percival, 'Debunking the Myth of "Particular Market Situation” in WTO Antidumping Law' (2016) 19(4) Journal of International Economic Law 863-892.

23 See Weihuan Zhou, 'Australia's Anti-Dumping and Countervailing Law and Practice: An Analysis of Current Issues Incompatible with Free Trade with China' (2015) 49(6) Journal of World Trade 9751010 at $980-990$.

24 Panel Report, European Union-Anti-Dumping Measures on Biodiesel from Argentina, WT/DS473/R, adopted 26 October 2016 (as modified by the Appellate Body Report); Appellate Body Report, Union-AntiDumping Measures on Biodiesel from Argentina, WT/DS473/AB/R, adopted 26 October 2016. 
Article 15 of China's Accession Protocol, ${ }^{25}$ they have provided greater clarity on whether surrogate production cost can be used for the determination of normal value under the AD Agreement. Beyond that, the significance of the Appellate Body report ${ }^{26}$ lies in its far-reaching implications for the reach of the AD Agreement; that is, whether the agreement and hence antidumping measures should be used to tackle price distortions associated with state intervention. This significance is further enhanced by the timeliness of the decision, given the expiration of the NME Methodology, the ongoing dispute over Article 15 of China's Accession Protocol, and the lack of WTO jurisprudence on how the term PMS should be interpreted and applied. ${ }^{27}$ In analysing the Appellate Body's rulings in EU-Biodiesel, this article will also discuss how the rulings shed light on the issue of PMS.

This article proceeds as follows. Section 2 offers a detailed analysis of the Appellate Body report on EU-Biodiesel, focusing on three key issues: (1) on what basis antidumping authorities may replace the actual input costs incurred by exporters with a surrogate input cost in determining normal value (i.e. Article 2.2.1.1 of the AD Agreement); (2) if a surrogate input cost is employed, whether the authorities are required to make adjustments to ensure the cost reflects the market conditions prevailing in the country of origin, and if so, how (i.e. Article 2.2 of the AD Agreement); and (3) what role Article 2.4 of the AD Agreement may play in the above context. Section 3 discusses the European Union's (EU) implementation of the Appellate Body's rulings in EU-Biodiesel and the implications of the rulings for the EU's ongoing reform of its antidumping legislation. Section 4 concludes.

\section{Appellate Body Report on EU-Biodiesel}

\subsection{The AD Agreement}

In EU-Biodiesel, the main task of the Appellate Body was to interpret the following provisions of the AD Agreement:

Article 2.2 When there are no sales of the like product in the ordinary course of trade in the domestic market of the exporting country or when, because of the particular market situation or the low volume of the sales in the domestic

25 Article 15 of China's Accession Protocol is currently the subject of a separate WTO dispute, see European Union-Measures Related to Price Comparison Methodologies (DS516), www.wto.org/ english/tratop_e/dispu_e/cases_e/ds516_e.htm.

26 This article will focus on the Appellate Body report. For a discussion of the panel report, see Weihuan Zhou and Andrew Percival, 'Panel Report on EU-Biodiesel: A Glass Half Full? - Implications for the Rising Issue of "Particular Market Situation" (2016) 2(2) Chinese Journal of Global Governance 142-163.

27 For a detailed discussion of the issue of PMS, see above note 22, Zhou and Percival, 'Debunking the Myth of "Particular Market Situation" in WTO Antidumping Law'. 
market of the exporting country, such sales do not permit a proper comparison, the margin of dumping shall be determined by comparison with a comparable price of the like product when exported to an appropriate third country, provided that this price is representative, or with the cost of production in the country of origin plus a reasonable amount for administrative, selling and general costs and for profits.

Article 2.2.1.1 For the purpose of paragraph 2, costs shall normally be calculated on the basis of records kept by the exporter or producer under investigation, provided that such records are in accordance with the generally accepted accounting principles of the exporting country and reasonably reflect the costs associated with the production and sale of the product under consideration. Authorities shall consider all available evidence on the proper allocation of costs, including that which is made available by the exporter or producer in the course of the investigation provided that such allocations have been historically utilized by the exporter or producer, in particular in relation to establishing appropriate amortization and depreciation periods and allowances for capital expenditures and other development costs. Unless already reflected in the cost allocations under this sub-paragraph, costs shall be adjusted appropriately for those nonrecurring items of cost which benefit future and/or current production, or for circumstances in which costs during the period of investigation are affected by startup operations. (emphasis added)

Under the AD Agreement, dumping occurs when a producer/exporter sells products to a foreign market at a price (i.e. export price) lower than the price of the goods sold in the domestic market (i.e. normal value). ${ }^{28}$ Thus, the calculation of normal value is critical for the determination of dumping, the magnitude of dumping margins, and the antidumping duties to be levied. Generally, a normal value should be established on the basis of the actual price of the subject goods in the market of exportation. However, Article 2.2 contemplates several circumstances in which investigating authorities may disregard domestic prices of subject goods and determine a normal value based on a constructed method by adding up the production cost, administrative, selling, and general ('SG\&A') costs in the domestic market, and the profit on the domestic sale (known as the 'Constructed Normal Value' ('CNV')). These circumstances include the following: (1) there are no domestic sales of the subject goods in the ordinary course of trade, (2) there is a PMS, or (3) the volume of domestic sales is low. A finding that any of these circumstances exists provides a pathway to using the constructed method under which the level of a CNV hinges on how costs and profit are established.

28 Article 2.1 of the AD Agreement provides: 'For the purpose of this Agreement, a product is to be considered as being dumped, i.e. introduced into the commerce of another country at less than its normal value, if the export price of the product exported from one country to another is less than the comparable price, in the ordinary course of trade, for the like product when destined for consumption in the exporting country.' 
In practice, surrogate input costs are frequently used to offset government-caused price distortions in raw materials markets. The issue is whether such use of surrogate costs is justified under Articles 2.2.1.1 and 2.2 of the AD Agreement. This was a major issue in the EU-Biodiesel dispute.

\subsection{The dispute}

The dispute arose out of the EU's imposition of antidumping duties on biodiesel exported from Argentina and Indonesia. ${ }^{29}$ In the preliminary determinations, the EU authorities found that domestic sales of biodiesel in Argentina were not made in the ordinary course of trade due to state intervention in the domestic biodiesel market. In calculating a CNV, the authorities employed the production costs recorded by the Argentinean producers under investigation but decided to further consider the impact of the Differential Export Tax ('DET') system under which Argentina imposed taxes on the exports of soybeans and soybean oil - the main raw materials used in the production of biodiesel. The provisional dumping margins were found to be between $6.8 \%$ and $10.6 \%$. In the final determinations, the EU authorities found that the DET system had created a PMS in the domestic raw materials market by artificially lowering the prices of soybeans and soybean oil, which were lower than the international prices essentially by the amount of the export taxes. Therefore, the records of the Argentinean producers were found not to reasonably reflect the raw materials costs and were replaced with the average reference prices of the raw materials published by the Argentine Ministry of Agriculture for the calculation of the CNV. The use of the surrogate input costs resulted in an increase of the provisional dumping margins to a range of $41.9 \%$ to $49.2 \%$.

Before the panel and the Appellate Body, Argentina challenged the EU Regulation 'as such' and 'as applied' in violation of a number of provisions of the AD Agreement.

\section{3 'As such' claim}

The 'as such' claim concerned Article 2(5) of the EU's Basic Regulation which states:

5. Costs shall normally be calculated on the basis of records kept by the party under investigation, provided that such records are in accordance with the generally accepted accounting principles of the country concerned and that it is shown that the records reasonably reflect the costs associated with the production and sale of the product under consideration.

29 Panel Report, EU-Biodiesel, paras. 2.2-2.3, 7.179-7.184; Appellate Body Report, paras. 5.1-5.10. The EU authorities' final decisions to impose the antidumping measures challenged in the dispute are trade. ec.europa.eu/tdi/case_history.cfm?id=1893\&init=1893. 
If costs associated with the production and sale of the product under investigation are not reasonably reflected in the records of the party concerned, they shall be adjusted or established on the basis of the costs of other producers or exporters in the same country or, where such information is not available or cannot be used, on any other reasonable basis, including information from other representative markets.

Argentina argued that the second paragraph of Article 2(5) of the EU Regulation mandates the EU authorities to reject production costs recorded by exporters if the costs have been found to be distorted or artificially low and hence did not reasonably reflect prices (i.e. a violation of Article 2.2.1.1), and subsequently to use costs other than those prevailing in the country of origin to construct normal value (i.e. a breach of Article 2.2). Both arguments were rejected by the panel and the Appellate Body.

On the alleged breach of Article 2.2.1.1, both the panel and the Appellate Body held that the second paragraph of Article 2(5) comes into play only after determinations have been made on whether production costs are 'reasonably reflected' in the producers' records under the first paragraph of that article. ${ }^{30}$ In other words, it is the first paragraph of Article 2(5) that should be subject to Argentina's claim of violation of Article 2.2.1.1; hence, Argentina's 'as such' claim was misplaced. Understandably, Argentina did not target the first paragraph, which reproduces Article 2.2.1.1 of the AD Agreement.

As far as the alleged violation of Article 2.2 is concerned, the panel found that the second paragraph of Article 2(5) does not require the EU authorities to replace producers' costs with costs in another country, but merely permits the authorities to 'establish or adjust the costs reported in the producers' records on the basis of information from other representative markets'. 31 In upholding the panel's finding, the Appellate Body observed that out-of-country information can be used to establish production costs as long as necessary adjustments are made to ensure the costs reflect the cost of production in the country of origin. ${ }^{32}$ While the second paragraph of Article 2(5) may be read to permit the EU authorities to "use "information from other representative markets", as the basis for arriving at the costs of production, without adapting it to reflect the costs of production in the country of origin', this is not mandatory. ${ }^{33}$

The panel and Appellate Body's rulings seem to be consistent with the existing WTO jurisprudence on the 'mandatory/discretionary distinction', that is, whether a member's measure mandates WTO-inconsistent acts (so that the measure is in violation 'as such') or merely provides authorities the discretion to do so (so that only the practical application of the measure may be found in

30 Panel Report, EU-Biodiesel, para. 7.153; Appellate Body Report, paras. 6.198, 6.237.

31 Panel Report, EU-Biodiesel, para. 7.169.

32 Appellate Body Report, EU-Biodiesel, para. 6.242.

33 Ibid., para. 6.243. 
breach of WTO rules). ${ }^{34}$ In the present dispute, the EU authorities were vested with the discretion in determining production costs in a way that is not inconsistent with the AD Agreement. That is, the discretion for the authorities to make adjustments to out-of-country information determines that an 'as such' violation of Article 2.2 cannot be established. Therefore, even though it is possible for the authorities to act inconsistently with the AD Agreement as they did in a series of cases, ${ }^{35}$ a breach of the agreement is not 'mandatory' and must be established on a case-by-case basis.

The ruling that out-of-country information may be used for the establishment of production costs in the country of exportation is sound, as it takes into account the possibility of the lack of domestic costs information. However, the Appellate Body did not elaborate on what adjustments should be made to ensure out-of-country information reflects the market condition prevailing in the exporting country. This issue will be further discussed below.

\section{4 'As applied' claim}

The panel ruled in favour of Argentina on all 'as applied' claims under Articles 2.2.1.1 and 2.2 of the AD Agreement, which were subsequently upheld by the Appellate Body.

\subsubsection{Article 2.2.1.1}

Under Article 2.2.1.1, investigating authorities are required to use the actual costs recorded by producers/exporters for the construction of normal value as long as the records comply with 'the generally accepted accounting principles' (GAAP) and 'reasonably reflect the costs associated with the production and sale of the product under consideration' ('Reasonably Reflecting Test'). At the core of the dispute was whether the Reasonably Reflecting Test includes a general standard of 'reasonableness' whereby costs must be reasonable and not distorted. The Appellate Body found that this test

[does not include] an additional or abstract standard of 'reasonableness' ... ${ }^{36}$

requires a comparison between the costs in the producer's or exporter's records and the costs incurred by such producer or exporter... 'the object of the comparison is to establish whether the records reasonably reflect the costs actually incurred, and not whether they reasonably reflect some hypothetical costs that might have been incurred under a different set of conditions or circumstances and which the investigating authority considers more 'reasonable' than the costs actually incurred. ${ }^{37}$ 
relates to whether the records kept by the exporter or producer under investigation suitably and sufficiently correspond to or reproduce those costs incurred by the investigated exporter or producer that have a genuine relationship with the production and sale of the specific product under consideration. ${ }^{38}$

Accordingly, the Appellate Body upheld the panel's finding that

the EU authorities' determination that domestic prices of soybeans in Argentina were lower than international prices due to the Argentine export tax system was not, in itself, a sufficient basis under Article 2.2.1.1 for concluding that the producers' records do not reasonably reflect the costs of soybeans associated with the production and sale of biodiesel, or for disregarding those costs when constructing the normal value of biodiesel. ${ }^{39}$

In essence, the rulings above establish that investigating authorities must use the production costs actually incurred by producers or exporters for the calculation of a CNV, even though the costs are considered to be 'distorted' or 'artificially lowered' due to state intervention. This is because the Reasonably Reflecting Test is confined to an assessment of whether the records suitably and sufficiently reflect the actual costs incurred and does not allow for consideration of the reasonableness of the costs themselves. On what the requirements of 'suitably', 'sufficiently', and 'having a genuine relationship with the production and sale of the specific product under consideration' may entail, the Appellate Body provided further clarification based on the remainder of Article 2.2.1.1, which essentially concerns the allocations and adjustments of costs in a way that reflects the costs actually incurred in the production of the subject goods by each exporter or producer under investigation. ${ }^{40}$

In the present case, the EU authorities' decision to use surrogate costs was based on a finding of PMS in the raw materials market, which, in turn, was based on the finding that the prices of soybeans and soybean oil were lower than the international prices due to the DET system. In rejecting the EU authorities' findings in the context of the Reasonably Reflecting Test, the Appellate Body clarified that as long as the recorded production costs suitably and sufficiently reflect the actual costs incurred, the existence of a PMS due to price distortions and state intervention by itself does not justify a deviation from an exporter's actual costs.

To be clear, the WTO tribunals in EU-Biodiesel did not examine what may constitute a PMS; nor did they exclude the possibility that the existence of a PMS may render production costs not reasonably reflected in producers' records. However, in the latter situation, evidence, in addition to state intervention and price distortion, must be adduced to determine whether recorded production costs reflect the actual costs incurred in the production of the subject goods. While the rulings

38 Ibid., para. 6.56 .

39 Panel Report, EU-Biodiesel, para. 7.248; Appellate Body Report, para. 6.55.

40 Appellate Body Report, EU-Biodiesel, para. 6.22. 
concerned export taxes, they suggest that price distortions caused by other trade or domestic instruments, such as export restrictions, domestic subsidies, or other government regulations and policies, standing alone, would also fail to justify not using the costs in the producers' books and records.

Accordingly, the Appellate Body's rulings come very close to the proposition that price distortions caused by state intervention, and a finding of PMS on that basis, is irrelevant to the determination of whether surrogate costs should be employed. In this connection, the Appellate Body rejected the EU's submission that production costs used for the calculation of a CNV must be those 'in normal circumstances, i.e. in the absence of the alleged distortion caused by Argentina's export tax system' ${ }^{41}$ This suggests that distorted production costs should still be used for the construction of normal value, as long as they reflect the prevailing conditions in the market of exportation.

The Appellate Body's rulings are sound. Government regulations exist in all markets; and such regulations, combined with various types of industrial financial assistance and other governmental measures, undoubtedly affect prices, either directly or indirectly. Thus, it is impossible to determine what price is 'reasonable' and whether chosen surrogate costs are completely free of government regulation or distortion. Furthermore, each country has its own market, which determines that production costs vary from country to country. The use of surrogate costs for the construction of normal value ignores the differences in the market conditions in different countries. Given the differences, one country can always treat the other as having a 'particular' market situation as it applies its own standards in determining what costs are reasonable. In rejecting state intervention and price distortion as being sufficient to justify a deviation from a producer's actual costs, the Appellate Body has adroitly avoided tit-for-tat abuse of surrogate costs through findings of state intervention and price distortions. Finally, if an exporter's actual cost of production is found to be distorted, it is reasonable to assume that such a distortion has affected or 'flowed through' to both the export price and the domestic price of the goods to the same extent, ${ }^{42}$ so that a proper comparison between the export price and the normal value would not be precluded. This offers an additional explanation as to why the Reasonably Reflecting Test should not concern price distortions. In the context of determining whether a PMS exists, this imposes an obligation on investigating authorities to establish that an alleged input price distortion has impacted on normal value and export price asymmetrically to justify the construction of normal value. ${ }^{43}$

41 Ibid., para. 6.30.

42 Thomas Prusa and Edwin Vermulst, 'United States - Definitive Anti-Dumping and Countervailing Duties on Certain Products from China: Passing the Buck on Pass-Through' (2013) 12(2) World Trade Review $197-234$ at 217-219.

43 This observation can be drawn from the Appellate Body's interpretation of the 'passing through' issue in the context of assessing the application of countervailing duties to tackling 'input subsidies' 
In light of the above, the Appellate Body's decision under Article 2.2.1.1, particularly on the Reasonably Reflecting Test, has ruled out the possibility that state intervention and price distortions alone would justify the use of surrogate costs for the construction of normal value. Hopefully, this would dissuade WTO members from abusing PMS or state intervention to effectively extend the NME Methodology.

\subsubsection{Article 2.2}

Under Article 2.2 of the AD Agreement, the tribunals made a significant distinction between the cost of production and the information used for the establishment of the cost. In the words of the Appellate Body,

In circumstances where the obligation in the first sentence of Article 2.2.1.1 to calculate the costs on the basis of the records kept by the exporter or producer under investigation does not apply, or where relevant information from the exporter or producer under investigation is not available, an investigating authority may have recourse to alternative bases to calculate some or all such costs. Yet, Article 2.2 does not specify precisely to what evidence an authority may resort. This suggests that, in such circumstances, the authority is not prohibited from relying on information other than that contained in the records kept by the exporter or producer, including in-country and out-of-country evidence. This, however, does not mean that an investigating authority may simply substitute the costs from outside the country of origin for the 'cost of production in the country of origin'. Indeed, Article 2.2 of the Anti-Dumping Agreement and Article VI:1(b)(ii) of the GATT 1994 make clear that the determination is of the 'cost of production ... in the country of origin'. Thus, whatever the information that it uses, an investigating authority has to ensure that such information is used to arrive at the 'cost of production in the country of origin'. Compliance with this obligation may require the investigating authority to adapt the information that it collects. ${ }^{44}$

The Appellate Body considered two specific circumstances (in footnotes) where outof-country information or evidence may need to be used. One is 'where the producer under investigation purchases inputs from outside the country of origin to produce the product under consideration'. ${ }^{45}$ However, in this circumstance, the Appellate Body seems to be concerned about the accuracy of the out-of-country information and not about whether the information reflects the market condition of the country of origin. ${ }^{46}$ The other circumstance pertains to 'where the producer under investigation refuses access to and does not provide information concerning costs, and the investigating authority relies on "best information available" under

under the SCM Agreement. See generally Appellate Body Report, United States-Final Countervailing Duty Determination with Respect to Certain Softwood Lumber from Canada, WT/DS257/AB/R, adopted 17 February 2004. Also see Sherzod Shadikhodjaev, 'How to Pass a Pass-Through Test: The Case of Input Subsidies' (2012) 15(2) Journal of International Economic Law 621-646 at 635-636.

44 Appellate Body Report, EU-Biodiesel, para. 6.73.

45 Ibid., FN 228.

46 Ibid. 
Article 6.8 and Annex II to the Anti-Dumping Agreement'. 47 The Appellate Body did not consider what adjustments may be required in these circumstances.

Accordingly, investigating authorities are allowed to use information or evidence in a different market or country to determine the cost of production in the exporting country under investigation. There appears to be no limitation on what information or evidence may be employed. However, out-of-country information can be used only when the conditions under Article 2.2.1.1 are satisfied, or in-country information is unavailable or is otherwise not provided. Furthermore, if out-ofcountry information is used, such information must be adjusted to reflect the cost of production in the country of origin.

On the use of the surrogate prices by the EU authorities, the Appellate Body, in upholding the panel's findings, ruled that the authorities had failed to make adjustments on the following ground:

Other than pointing to the deduction of fobbing costs, the European Union has not asserted, either before the Panel or before us, that the EU authorities adapted, or even considered adapting, the information used in their calculation in order to ensure that it represented the cost of production in Argentina. On the contrary, the EU authorities specifically selected the surrogate price for soybeans to remove the perceived distortion in the cost of soybeans in Argentina. As the Panel stated, the EU authorities selected and used this particular information precisely because it did not represent the cost of soybeans in Argentina. Thus, we agree with the Panel that the surrogate price for soybeans used by the EU authorities did not represent the cost of soybeans in Argentina for producers or exporters of biodiesel. ${ }^{48}$ (emphasis added)

This ruling suggests that an adjustment must be made to the surrogate costs to ensure the costs used for the construction of normal value reflect the price distortions associated with the DET system and hence the market conditions in Argentina. It also suggests that no matter what cost information or evidence is employed to determine the production cost of a producer or exporter in the country under investigation, the practice of using surrogate costs must not be conducted in such a way that disregards the policy and regulatory environment of the country which may have directly or indirectly affected input prices. For example, if surrogate costs are used based on a finding of PMS, adjustments must be made to reinstitute any price distortions associated with the PMS into the surrogate costs. Accordingly, while the Appellate Body did not provide full clarity on all types of adjustments, it challenged head-on the rampant antidumping practice of using surrogate input costs to construct normal value in order to inflate dumping margins. The rulings on adjustments reinforce the rulings on the Reasonably Reflecting Test and impose an additional disincentive for antidumping authorities to abuse surrogate prices. 
On the use of surrogate prices, Article 14(d) of the SCM Agreement provides a comparable context. It states:

the provision of goods or services or purchase of goods by a government shall not be considered as conferring a benefit unless the provision is made for less than adequate remuneration, or the purchase is made for more than adequate remuneration. The adequacy of remuneration shall be determined in relation to prevailing market conditions for the good or service in question in the country of provision or purchase (including price, quality, availability, marketability, transportation and other conditions of purchase or sale). (emphasis added)

In US-Softwood Lumber IV, the US authority found that the Canadian prices of stumpage did not reflect competitive market prices and hence applied benchmark prices based on stumpage prices in the US to determine adequacy of remuneration. ${ }^{49}$ The Appellate Body observed that

investigating authorities may use a benchmark other than private prices in the country of provision under Article 14(d), if it is first established that private prices in that country are distorted because of the government's predominant role in providing those goods. ${ }^{50}$

However, unlike Article 2.2 of the AD Agreement and EU-Biodiesel, the reason why price distortions caused by state intervention constitute a basis for the use of benchmark prices under Article 14(d) of the SCM Agreement is that government influence on private prices would preclude the measurement of benefit conferred by subsidies. ${ }^{51}$ Therefore, this ruling is specific to the purpose of Article 14(d) and does not affect the Appellate Body's rulings in EU-Biodiesel and the discussions above.

In the same case, the Appellate Body also held that

where an investigating authority proceeds in this manner, it is under an obligation to ensure that the resulting benchmark relates or refers to, or is connected with, prevailing market conditions in the country of provision, and must reflect price, quality, availability, marketability, transportation and other conditions of purchase or sale, as required by Article 14(d). ${ }^{52}$

However, the Appellate Body had insufficient evidence to determine whether the US had made proper adjustments and merely recognized that it may be difficult for investigating authorities to make all adjustments to replicate market conditions prevailing in the country under investigation. ${ }^{53}$ Towards this end, the Appellate Body offered an enlightening remark:

49 Appellate Body Report, United States - Final Countervailing Duty Determination with respect to Certain Softwood Lumber from Canada, WT/DS257/AB/R, adopted 17 February 2004, para. 77.

50 Ibid., para. 90.

51 Ibid., paras. 93, 100-101.

52 Ibid., para. 106.

53 Ibid., para. 108. 
It is clear, in the abstract, that different factors can result in one country having a comparative advantage over another with respect to the production of certain goods. In any event, any comparative advantage would be reflected in the market conditions prevailing in the country of provision and, therefore, would have to be taken into account and reflected in the adjustments made to any method used for the determination of adequacy of remuneration, if it is to relate or refer to, or be connected with, prevailing market conditions in the market of provision. This is because countervailing measures may be used only for the purpose of offsetting a subsidy bestowed upon a product, provided that it causes injury to the domestic industry producing the like product. They must not be used to offset differences in comparative advantages between countries. ${ }^{54}$

This remark suggests that if benchmark prices are employed, adjustments must be made to fully reflect the comparative advantage that the country of origin gains from its factor endowments. This raises an issue whether adjustments of benchmark/surrogate prices should be required if a comparative advantage is created by state intervention. In the context of determining the benefits conferred by subsidies, such adjustments are not required according to the Appellate Body's rulings in US-Softwood Lumber IV above. In contrast, the Appellate Body's decision in EU-Biodiesel suggests that in the context of determining dumping margins, adjustments of surrogate prices must be made to reflect price distortions caused by state intervention in the country under investigation. Accordingly, it is submitted that government-caused price distortions are not intended to be dealt with under the AD Agreement unless otherwise specified in the agreement (i.e. Article 2.7 of the agreement which refers to the second interpretative note to GATT Article VI:1). ${ }^{55}$ Thus, Articles 2.2 and 2.2.1.1 of the AD Agreement do not concern state interference but should focus on business practices of companies that amount to price differentiation between different markets. Rather, state intervention should be dealt with under the other WTO agreements such as the SCM Agreement and the GATT 1994.

In US-Carbon Steel (India), the Appellate Body observed that 'prevailing market conditions', in the context of Article 14(d) of the SCM Agreement, consist of generally accepted characteristics of an area of economic activity in which the forces of supply and demand interact to determine market prices. ${ }^{56}$ By referring to US-Softwood Lumber IV, the Appellate Body confirmed that to allow for an assessment of adequacy of remuneration, 'any benchmark for conducting such an assessment must consist of market-determined prices for the same or similar goods that relate or refer to, or are connected with, the prevailing market

54 Ibid., para. 109.

55 See supra pp. 2-3.

56 Appellate Body Report, United States - Countervailing Measures on Certain Hot-Rolled Carbon Steel Flat Products from India, WT/DS436/AB/R, adopted 19 December 2014, para. 4.150. 
conditions for the good in question in the country of provision'. ${ }^{57}$ As discussed above, this ruling does not affect the Appellate Body's decision in EU-Biodiesel; rather, it lends support to the view that price distortions associated with state intervention should not be dealt with under the AD Agreement.

On the adjustment of benchmark prices, the Appellate Body found that 'the illustrative list of "prevailing market conditions" parenthetically identified in the second sentence of Article 14(d) - "price, quality, availability, marketability, transportation and other conditions of purchase or sale" - are all factors that may affect the comparability of a benchmark price with the financial contribution at issue'. ${ }^{5}$ The Appellate Body considered that when ex-factory benchmark prices are used, an adjustment must be made to include the transportation costs generally applicable in the country of origin. ${ }^{59}$ This adjustment suggests that the adjustments required to be made under Article 14(d) of the SCM Agreement are similar to those contemplated under Article 2.4 of the AD Agreement. However, to the extent that the adjustments under Article 14(d) do not require consideration of governmentcaused price distortions, the adjustments required under Article 2.2 of the AD Agreement would be fundamentally different. The latter, according to the EUBiodiesel decision discussed above, requires adjustments of surrogate production costs so that the costs used for the construction of normal value reflect the relevant price distortions caused by state intervention.

\subsubsection{Article 2.4}

Another important issue in EU-Biodiesel concerns Argentina's contention under Article 2.4 of the AD Agreement which provides

A fair comparison shall be made between the export price and the normal value. This comparison shall be made at the same level of trade, normally at the exfactory level, and in respect of sales made at as nearly as possible the same time. Due allowance shall be made in each case, on its merits, for differences which affect price comparability, including differences in conditions and terms of sale, taxation, levels of trade, quantities, physical characteristics, and any other differences which are also demonstrated to affect price comparability.

Argentina argued that the EU authorities had failed to make due allowance for the difference between the CNV and the export price in accordance with Article 2.4. Fair comparison between the two prices cannot be achieved unless an adjustment was made to the difference arising from the use of different cost bases in the determination of the CNV (based on the surrogate price) and the export price (based on the actual production cost). 
The panel rejected the contention on the grounds that (1) Article 2.4 concerns 'differences in characteristics of the compared transactions that have an impact, or are likely to have an impact, on the prices involved in the transaction', and does not require adjustment of differences resulting from the methodology employed in the calculation of export price and normal value; ${ }^{60}$ and (2) the alleged difference arose exclusively from the methodology used by the EU authorities to construct a normal value based on surrogate prices and hence did not affect the price comparability of the two prices. ${ }^{61}$

The Appellate Body overruled the panel's finding that there is a 'general proposition that differences arising from the methodology applied for establishing the normal value cannot, in principle, be challenged under Article 2.4 as "differences affecting price comparability", holding that

The Appellate Body report in EC-Fasteners (China) (Article 21.5 - China) does not contain any such 'general proposition'. The reasoning in that report is tailored to the circumstances of that dispute, in which the analogue country methodology was used. The Appellate Body explained that Article 2.4 of the Anti-Dumping Agreement had to be read in the context of the second Ad Note to Article VI:1 of the GATT 1994 and Section 15(a) of China's Accession Protocol. Neither of those provisions is relevant for purposes of this dispute. Moreover, we would have serious reservations regarding what the Panel referred to as the 'general proposition'. The text of Article 2.4 itself makes clear that '[d]ue allowance shall be made in each case, on its merits'. This indicates that the need to make due allowance must be assessed in light of the specific circumstances of each case. ${ }^{62}$ (original emphasis)

However, given its findings under Articles 2.2.1.1 and 2.2, the Appellate Body found it unnecessary to determine "whether the EU authorities also failed to conduct a "fair comparison" in comparing the constructed normal value to the export price'. 63

The author has argued elsewhere that the panel's distinction between 'methodology-resulted' differences and 'transaction-resulted' differences is unjustified as Article 2.4 concerns whether the comparability of export price and normal value has been affected by an alleged difference, not how or in what circumstances the difference arises. ${ }^{64}$ The difference at issue, which was equivalent to the export tax, did affect the comparability between the CNV and the export price, and hence should be adjusted to ensure fair comparison. An adjustment of the difference is required to avoid the inflations of dumping margins that eventuated in EU-Biodiesel.

60 Panel Report, EU-Biodiesel, paras. 7.294-7.296.

61 Ibid., paras. 7.299-7.302.

62 Appellate Body Report, EU-Biodiesel, para. 6.87.

63 Ibid., para. 6.89 .

64 See above note 26, Zhou and Percival, 'Panel Report on EU-Biodiesel', at 154-155. 
The panel also misinterpreted the Appellate Body's rulings in EC-Fasteners (China) (Article 21.5 - China) which concerned the EU's application of the NME Methodology against China and use of surrogate costs in calculating a CNV. On the issue of whether the EU was required to make due allowances for cost differences alleged by China, the Appellate Body ruled in that case:

Article 2.4 of the Anti-Dumping Agreement has to be read in the context of the second Ad Note to Article VI:1 of the GATT 1994 and Section 15(a) of China's Accession Protocol. We recall that the rationale for determining normal value on the basis of [the surrogate prices] was that the Chinese producers had not clearly shown that market economy conditions prevail in the fasteners industry in China. [footnote omitted] Costs and prices in the Chinese fasteners industry thus cannot, in this case, serve as reliable benchmarks to determine normal value. In our view, the investigating authority is not required to adjust for differences in costs between the NME producers under investigation and the analogue country producer where this would lead the investigating authority to adjust back to the costs in the Chinese industry that were found to be distorted. ${ }^{65}$ (emphasis added)

In EU-Biodiesel, the Appellate Body clarified that the previous ruling applies only to the circumstances in which the AD Agreement or other WTO instruments such as Accession Protocols explicitly allow the replacement of actual costs with surrogate prices for the construction of normal value on the sole basis of state intervention and price distortion. In such circumstances, investigating authorities are not required to make adjustments to the cost difference arising from the distortion, because such an adjustment would result in reintroducing the distortion into the CNV. ${ }^{66}$ However, in other circumstances where price distortions caused by government intervention are not explicitly regulated (e.g. Articles 2.2 and 2.2.1.1 of the AD Agreement), price differences arising from the use of undistorted surrogate costs would still be subject to adjustments under Article 2.4.

The Appellate Body did not explain, however, how the adjustments under Article 2.4 should operate with the adjustments required under Article 2.2 to ensure surrogate costs reflect the market conditions prevailing in the country of origin. Apparently, when a price difference is related to a government-caused price distortion, the adjustment required under Articles 2.2 and 2.4 would deal with the same difference. In EU-Biodiesel, the difference is essentially the export tax, which was factored into the export price but not the CNV. The Appellate Body seems to have deliberately exercised judicial economy on whether the EU authorities failed to make adjustments under Article 2.4 to allow some time for it to consider this overlapping issue. However, the Appellate Body observed that

65 Appellate Body Report, European Communities-Definitive Anti-Dumping Measures on Certain Iron or Steel Fasteners from China (Recourse to Article 21.5 of the DSU by China), WT/DS397/AB/ RW, adopted 12 February 2016, para. 5.207.

66 Appellate Body Report, EU-Biodiesel, FN 270. 
[t]he manner in which the normal value is calculated pursuant to Article 2.2 of the Anti-Dumping Agreement may inform the types of adjustments required under Article 2.4. This, however, does not mean that any adjustment envisaged under Article 2.4 - in particular adjustments for taxation - may instead be taken into account in determining the normal value pursuant to Article 2.2.67

This observation, read together with the Appellate Body's rulings under Article 2.2, suggests that if a distortion-caused difference is adjusted under Article 2.2, it would be unnecessary to make the same adjustment under Article 2.4. However, allowing such adjustment to be made under Article 2.2 would not render Article 2.4 superfluous as price difference arising from other factors would still be adjusted under Article 2.4. Despite the uncertainty over the overlapping issue, the Appellate Body's rulings under Article 2.4 are consistent with its rulings under Articles 2.2 and 2.2.1.1, seeking to use adjustments to prevent abuse of surrogate production costs, and to offset unjustified inflations of dumping margins.

\subsection{4 (In)flexibilities under the AD Agreement to deal with government intervention}

The remaining question is to what extent the EU-Biodiesel decision leaves flexibility in dealing with state-caused price distortion under the AD Agreement, particularly in the construction of normal value. In the author's view, such flexibilities have been largely removed and will likely depend on the interpretation of the term 'in the ordinary course of trade'.

In EU-Biodiesel, the Appellate Body contemplated several scenarios which may satisfy the Reasonably Reflecting Test, including:

if certain costs relate to the production both of the product under consideration and of other products, or where the exporter or producer under investigation is part of a group of companies in which the costs of certain inputs associated with the production and sale of the product under consideration are spread across different companies' records, or where transactions involving such inputs are not at arm's length. ${ }^{68}$

With the exception of the last scenario, all concern whether production costs are reasonably allocated rather than whether the costs themselves are reasonable. The last example deals with situations where raw materials are not purchased at arm's length prices, e.g. between related parties. As such, the 'arms-length' test seems to fall within the test of whether sales are made 'in the ordinary course of trade'. In this connection, the Appellate Body observed that

Article 2.2 of the Anti-Dumping Agreement concerns the establishment of the normal value through an appropriate proxy for the price of the like product in 
the ordinary course of trade in the domestic market of the exporting country when the normal value cannot be determined on the basis of domestic sales. [footnote omitted] The costs calculated pursuant to Article 2.2.1.1 of the AntiDumping Agreement must be capable of generating such a proxy. This supports the view that the 'costs associated with the production and sale of the product under consideration' in Article 2.2.1.1 are those costs that have a genuine relationship with the production and sale of the product under consideration. This is because these are the costs that, together with other elements, would otherwise form the basis for the price of the like product if it were sold in the ordinary course of trade in the domestic market. ${ }^{69}$

While the 'ordinary course of trade' test may be read as involving a consideration of the reasonableness of the purchase price of inputs, it leaves little room for consideration of price distortions associated with state intervention. ${ }^{70}$ In US-HotRolled Steel, in considering the WTO-consistency of the treatment of sales between affiliated parties under the US antidumping law, the Appellate Body clarified that this test concerns whether the terms and conditions for a transaction are compatible with normal commercial practice for such transactions in the market in question. ${ }^{71}$ Therefore, it deals with business activities which cause the transaction prices of inputs lower or higher than arm's length prices, ${ }^{72}$ not state influence on or regulation of prices. Furthermore, this test concerns not only prices but also other terms and conditions of the transactions. ${ }^{73}$ Therefore, in determining whether sales are made 'in the ordinary course of trade', investigating authorities must rely on an objective assessment of the terms and conditions of commercial transactions, regardless of whether there is state intervention in the market. Indeed, state intervention such as state trading may result in sales not in the ordinary course of trade'. However, state intervention, at best, provides indirect evidence for, and does not satisfy, the 'ordinary course of trade' test.

In addition to production cost, the Appellate Body in EU-Biodiesel has also restricted the assessment of the reasonableness of SG\&A costs and profit to the 'ordinary course of trade' test. It stressed that the reference to a 'reasonable' amount for SG\&A costs and profit under Article 2.2 does not provide 'unfettered discretion' to investigating authorities and is subject to 'the concrete rules set out in

69 Ibid., para. 6.24 .

70 See Stéphanie Noël and Weihuan Zhou, 'Replacing the Non-Market Economy Methodology: Is the European Union's Alternative Approach Justified Under the World Trade Organization Anti-Dumping Agreement?' (2016)11(11/12) Global Trade and Customs Journal 559-567 at 563-565; Stéphanie Noël, "Why the European Union Must Dump So-Called "Non-Market Economy" Methodologies and Adjustments in Its Anti-Dumping Investigations' (2016)11(7/8) Global Trade and Customs Journal 296-305 at 302-304.

71 Appellate Body Report, United States-Anti-Dumping Measures on Certain Hot-Rolled Steel Products from Japan, WT/DS184/AB/R, adopted 23 August 2001, para. 140.

72 Ibid., paras. $141,143$.

73 Ibid., para. 142. 
Article 2.2.2' ${ }^{74}$ Under Article 2.2.2, investigating authorities must use actual data recorded by producers for SG\&A costs and profit as long as the data pertain to 'production and sales in the ordinary course of trade'. Accordingly, a determination of SG\&A costs and profit for the construction of normal value is also confined to consideration of normal business activities, providing no room for the use of benchmarks on the sole basis of state intervention and price distortions. As in the case of production cost, Article 2.2.2 also limits the alternative ways to establish SG\&A costs and profit to the use of sales information in the country of origin. Applying the EU-Biodiesel decision on Article 2.2 as discussed above, this means that a finding of price distortions associated with government intervention would not justify the use of external benchmarks, and that the SG\&A costs and profit used for the construction of normal value must reflect the prevailing market conditions, including any government-caused distortions, in the country under investigation.

\section{The EU's compliance with the EU-Biodiesel decision and new anti-dumping methodology}

The EU and Argentina initially agreed that the reasonable period of time for the EU to comply with the Appellate Body's rulings in EU-Biodiesel shall expire on 10 August 2017, but then agreed to extend that time to 28 September $2017 . .^{75}$ On 18 September 2017, the EU notified the Dispute Settlement Body of its implementation of the EU-Biodiesel decision. ${ }^{76}$ In essence, the EU's implementation measure modified its original dumping decisions through a recalculation of the $\mathrm{CNV}$ based on the actual costs incurred as reflected in the Argentine producers' records. ${ }^{77}$ As a result of the recalculation, the antidumping duties were reduced to a range from $4.5 \%$ to $8.1 \% .^{78}$ The EU authorities took the view that the EU-Biodiesel decision does not allow the use of surrogate production costs because the actual production costs incurred were adequately and faithfully reflected in the companies' records. ${ }^{79}$ However, the EU authorities observed that the EU-Biodiesel decision left the flexibility for investigating authorities to disregard actual production costs if

74 Appellate Body Report, EU-Biodiesel, para. 6.39 \& FN 172.

75 See European Union-Anti-Dumping Measures on Biodiesel from Argentina, Agreement under Article 21.3(B) of the DSU, WT/DS473/16 (15 December 2016); European Union-Anti-Dumping Measures on Biodiesel from Argentina, Agreement under Article 21.3(B) of the DSU, WT/DS473/18 (14 August 2017).

76 See European Union - Anti-Dumping Measures on Biodiesel from Argentina, Status Report by the European Union, WT/DS473/17/Add.3 (19 September 2017).

77 See Commission Implementing Regulation (EU) 2017/1578 of 18 September 2017, amending Implementing Regulation (EU) No. 1194/2013 imposing a definitive anti-dumping duty and collecting definitively the provisional duty imposed on imports of biodiesel originating in Argentina and Indonesia, para. 55 .

78 Ibid., para. 86.

79 Ibid., paras. 52-53. 
such 'costs had been, e.g. over- or understated or whether non-arm length transactions or other practices had affected the reliability of the reported costs'. ${ }^{80}$ The EU authorities' interpretation of the Appellate Body Report on EU-Biodiesel seems to be consistent with the author's analysis above.

Given the EU's understanding of the EU-Biodiesel decision, it would be interesting to see how the EU is to reconcile its proposed new antidumping methodology with the EU-Biodiesel decision. Since 2016, the EU has been revising its antidumping laws, seeking to create an approach that mirrors the NME Methodology. It has been proposed that under the new approach, the NME list will be replaced by a country-neutral methodology, which is primarily aimed at addressing market distortions caused by state intervention. ${ }^{81}$ The main section of the proposal is set out below:

There are circumstances however in which the domestic prices and costs would not provide a reasonable basis to determine the normal value. This could be the case, for instance, when prices or costs are not the result of free market forces because they are affected by government intervention. Relevant considerations in this respect include, for instance, the fact that the market in question is to a significant extent served by enterprises which operate under the ownership, control or policy supervision or guidance of the authorities of the exporting country; the state presence in firms allowing the state to interfere with respect to prices or costs; the existence of public policies or measures discriminating in favour of domestic suppliers or otherwise influencing free market forces; and the access to finance granted by institutions implementing public policy objectives.

In such circumstances, it would be inappropriate to use domestic prices and costs to determine the value at which the like product should be normally sold ('the normal value') and a new provision (Article 2(6)a) stipulates that the normal value would instead be constructed on the basis of costs of production and sale reflecting undistorted prices or benchmarks. For this purpose, the sources that may be used would include undistorted international prices, costs, or benchmarks, or corresponding costs of production and sale in an appropriate representative country with a similar level of economic development as the exporting country.

This methodology would allow the Commission to establish and measure the actual magnitude of dumping being practiced in normal market conditions absent distortions. ${ }^{82}$ (emphasis added)

80 Ibid., para. 51.

81 European Commission, 'Commission Proposes Changes to the EU's Anti-Dumping and AntiSubsidy Legislation', Press Release (9 November 2016), europa.eu/rapid/press-release_IP-16-3604_en.htm.

82 European Commission, 'Proposal for a Regulation of the European Parliament and of the Council amending Regulation (EU) 2016/1036 on protection against dumped imports from countries not members of the European Union and Regulation (EU) 2016/1037 on protection against subsidised imports from 
In the latest press release of the European Council, it was confirmed that ' $[w]$ hen a significant distortion is recognized in an exporting country', the new methodology would allow the Commission to 'set a price for the product by referring either to the costs of production and sale prices in a country with similar levels of economic development or to appropriate undistorted international costs and prices' ${ }^{83}$ It is intended that the new methodology would lead to the same level of antidumping duties as the EU had been able to impose through the NME Methodology. ${ }^{84}$

The EU's new antidumping methodology is currently under negotiations with the European Parliament; ${ }^{85}$ hence, it remains unclear what its final form will be and how it will be implemented in practice. In its current form, it is hard to imagine how the new methodology can be reconciled with the Appellate Body's rulings in EU-Biodiesel. Arguably, the wording of the new methodology and the outcomes that it is intended to achieve demonstrate an overt breach of the EU-Biodiesel decision. In other words, the new methodology allows the use of surrogate costs on the sole basis of state intervention and price distortions for the purpose of offsetting the distortions, thereby amounting to the use of production costs which do not reflect the market conditions prevailing in the country of exportation for the construction of normal value. An application of the new methodology by the EU authorities in antidumping investigations would constitute an 'as applied' violation of Articles 2.2.1.1 and 2.2 of the AD Agreement. Whether an 'as such' breach could be established will depend on the exact wording of the EU law which incorporates the new methodology. 86

\section{Conclusion}

In summary, the Appellate Body's decision in EU-Biodiesel has the following implications:

countries not members of the European Union', COM(2016)721 final, 9 November 2016, eur-lex.europa. eu/procedure/EN/2016_351. For a more detailed analysis of the new proposal, see Andrei Suse, 'Old Wine in A New Bottle: The EU's Response to the Expiry of Section 15(A)(II) of China's WTO Protocol of Accession', Leuven Centre for Global Governance Studies Working Paper No. 186, May 2017, 1-31 at $16-21$.

83 See European Council, 'Anti-Dumping Methodology: Council Agrees Negotiating Position', Press Release (3 May 2017), www.consilium.europa.eu/en/press/press-releases/2017/05/03-anti-dumping/.

84 See European Commission, 'Joint Press Conference by Jyrki Katainen, Vice-President of the EC, and Cecilia Malmström, Member of the EC, on the Treatment of China in Anti-Dumping Investigations', 20 July 2016, ec.europa.eu/avservices/video/player.cfm?ref=I124960.

85 See European Parliament, 'Anti-Dumping: More Robust Rules to Defend EU Industry and Jobs', 5 July 2017, www.europarl.europa.eu/news/en/press-room/20170629IPR78656/anti-dumping-more-robustrules-to-defend-eu-industry-and-jobs.

86 For a discussion of a potential 'as such' violation based on the proposed text, see above note 82 , Suse, 'The EU's Response to the Expiry of Section 15(A)(II) of China's WTO Protocol of Accession', at $26-29$. 
1. State intervention and resultant price distortions do not constitute sufficient ground for the use of surrogate production cost for the construction of normal value. The Reasonably Reflecting Test under Article 2.2.1.1 of the AD Agreement concerns whether the cost records of producers or exporters suitably and sufficiently reflect the actual costs incurred by the producers or exporters in the production of the subject goods, and does not allow for consideration of whether the costs reflect competitive market prices.

2. The terms 'suitably' and 'sufficiently' leave no room for consideration of price distortions caused by state intervention. They concern business activities, including whether production costs are reasonably and accurately allocated to the subject goods or whether the terms and conditions for the sale of the inputs at issue are compatible with normal commercial practice for such sales in the market concerned.

3. The production costs used for the construction of normal value must reflect the market conditions prevailing in the country of exportation. Such market conditions include government policies and regulations that directly or indirectly affect prices. Therefore, if surrogate prices are employed to counteract price distortions, adjustments to such prices must be made to reintroduce the distortions into the production costs.

4. If the adjustments contemplated under point 3 are not made, then adjustments of the difference between the CNV and the export price which are established using different cost bases (i.e. undistorted vs. distorted) must be made under Article 2.4 to ensure fair comparison between the two prices.

While the EU-Biodiesel decision does not offer clarifications on the meaning of PMS, it applies to the use of PMS on the basis of state intervention and price distortions as a pathway to the use of surrogate costs and ultimately to inflating dumping margins. This pathway is unequivocally closed by the Appellate Body in the case. Towards this end, the flexibility to deal with state intervention and price distortions under the AD Agreement (if any) predominantly hinges on the interpretation and application of the 'ordinary course of trade' test. However, the existing WTO jurisprudence strongly suggests that this test concerns business activities (i.e. terms and conditions of commercial transactions) rather than state intervention. Read together with the relevant WTO jurisprudence on the 'ordinary course of trade' test and subsidies, the EU-Biodiesel decision indicates that state intervention and price distortions should be dealt with under other WTO rules such as the SCM Agreement, leaving the AD Agreement to focus on business practices, particularly pricing behaviours of producers or exporters, that result in price differentiation between domestic and foreign markets.

The EU-Biodiesel case is the first WTO Appellate Body decision which starts to remove the flexibility of condemning state intervention and price distortions through antidumping measures. However, given the past and current practice, it would be realistic to recognize that antidumping will continue to be applied in this manner either in overt violation of the EU-Biodiesel decision or through 
creative utilization of the flexibilities (if any) left by the decision. In the case of China, China's unique economic system and significant state-trading practices will remain a major concern of its trading partners, and will continue to attract antidumping actions. The adequacy of the world trade rules in dealing with China will be increasingly debated and tested. However, the EU-Biodiesel decision suggests that these debates should be moved away from the AD Agreement and the use of antidumping measures and focus on other WTO rules. Therefore, to protect the credibility of the WTO dispute settlement mechanism, member states should shift their focus to, and seek to explore the capacity of, the other WTO rules to overcome the challenges arising from China's state capitalism. 